\title{
De videoreconstructie in het strafproces
}

Citation for published version (APA):

van Manen, J. W. (2021). De videoreconstructie in het strafproces: van verbeelding naar juridische werkelijkheid. [, Maastricht University]. Maastricht University. https://doi.org/10.26481/dis.20211104jm

Document status and date:

Published: 01/01/2021

DOI:

10.26481/dis.20211104jm

Document Version:

Publisher's PDF, also known as Version of record

\section{Please check the document version of this publication:}

- A submitted manuscript is the version of the article upon submission and before peer-review. There can be important differences between the submitted version and the official published version of record.

People interested in the research are advised to contact the author for the final version of the publication, or visit the DOI to the publisher's website.

- The final author version and the galley proof are versions of the publication after peer review.

- The final published version features the final layout of the paper including the volume, issue and page numbers.

Link to publication

\footnotetext{
General rights rights.

- You may freely distribute the URL identifying the publication in the public portal. please follow below link for the End User Agreement:

www.umlib.nl/taverne-license

Take down policy

If you believe that this document breaches copyright please contact us at:

repository@maastrichtuniversity.nl

providing details and we will investigate your claim.
}

Copyright and moral rights for the publications made accessible in the public portal are retained by the authors and/or other copyright owners and it is a condition of accessing publications that users recognise and abide by the legal requirements associated with these

- Users may download and print one copy of any publication from the public portal for the purpose of private study or research.

- You may not further distribute the material or use it for any profit-making activity or commercial gain

If the publication is distributed under the terms of Article $25 \mathrm{fa}$ of the Dutch Copyright Act, indicated by the "Taverne" license above, 


\section{Bijlage $5 \quad$ Samenvatting}

In dit onderzoek staat de videoreconstructie in het Nederlandse strafproces centraal. Vanaf de aanvang van een strafrechtelijk onderzoek worden door verschillende bij de rechtshandhaving betrokken functionarissen uiteenlopende reconstructiemethoden toegepast om meer duidelijkheid te krijgen over de toedracht van de onderzochte gebeurtenis. Een van die reconstructiemethoden is de videoreconstructie. Hierbij wordt door en op aanwijzing van personen, die bij de gebeurtenis betrokken zijn geweest, in de rol van verdachte of getuige, meestal op de oorspronkelijke locatie en onder vergelijkbare omstandigheden als tijdens de gebeurtenis het verloop van de betreffende gebeurtenis nagespeeld. Deze reconstructies vinden plaats op verzoek en in aanwezigheid van de professionele procespartijen en worden audiovisueel geregistreerd.

De auteur van deze dissertatie maakt deel uit van het Landelijk Video Reconstructie Team (LVRT) en heeft een groot aantal jaren ervaring met videoreconstructies. Hij heeft zich in zijn promotieonderzoek de vraag gesteld hoe de wijze waarop die videoreconstructies worden uitgevoerd zich verhoudt tot de wet- en regelgeving en rechtspsychologische inzichten. Deze behoefte wordt versterkt door het ontbreken van richtlijnen en publicaties van wetenschappelijk onderzoek over deze reconstructiemethode.

Met een videoreconstructie blijkt vrijwel altijd waarheidsvinding te worden nagestreefd. De centrale vraag van dit onderzoek luidt dan ook: 'Welke bijdrage levert een videoreconstructie aan de waarheidsvinding in het strafproces en op welke wijze kan die bijdrage worden geoptimaliseerd?' Bij het onderzoek is uitgegaan van strafrechtelijke waarheidsvinding, die bestaat uit de reconstructie van de feiten ten behoeve van het nemen van strafrechtelijke beslissingen. In de dissertatie worden de raison d'etre en het verloop van de videoreconstructie geanalyseerd in relatie tot de bewijsvoering en aspecten van het eerlijk proces, zoals 'equality of arms'; de nadruk ligt in de wetenschappelijke beschouwing op de rechtmatigheid en de betrouwbaarheid van de videoreconstructie.

Naast literatuur en (media-)berichten is gebruik gemaakt van verschillende bronnen, zoals de resultaten van een enquête, gehouden onder vertegenwoordigers van de professionele procespartijen, waarvan vrijwel allen ervaring hebben met videoreconstructies. Ook is een zakenonderzoek uitgevoerd. Hierbij zijn over de periode 2000-2015 de zaken onderzocht waarin een videoreconstructie is uitgevoerd en waarvan de uitspraak op www.rechtspraak.nl is gepubliceerd. Dit zijn in totaal 93 zaken, waarvan er 90 zijn begeleid door het LVRT. Verder is informatie verzameld en geanalyseerd afkomstig uit het archief van het LVRT, is een aantal dossiers bij de gerechten onderzocht en is onderzoek gedaan naar de door het LVRT begeleide videoreconstructies in genoemde periode, die niet zijn gepubliceerd. Het LVRT blijkt namelijk in genoemde periode 243 videoreconstructies te hebben begeleid en geregistreerd.

De dissertatie is als volgt opgebouwd. Om een indruk te krijgen van het verloop en de essentie van een videoreconstructie is na het eerste inleidende hoofdstuk een fictieve casus weergegeven. De lezer wordt aan de hand hiervan vertrouwd gemaakt met de verschillende stappen vanaf het voornemen tot het uitvoeren van een videoreconstructie tot aan het 
gebruik en het beoordelen van het resultaat op de terechtzitting. Ook biedt deze casus inzicht in de betrokkenen en hun rol bij de videoreconstructie en wordt een aantal aandachtspunten bij de voorbereiding en uitvoering benoemd.

In hoofdstuk 3 is een aantal kwantitatieve en kwalitatieve gegevens betreffende de videoreconstructie in Nederland vermeld. Daarin wordt ook het LVRT nader beschreven. Dit is een team dat in opdracht van de rechter of het openbaar ministerie landelijk opereert en bestaat uit politiemensen die werkzaam zijn bij de Dienst Regionale Recherche in OostBrabant. De leden van dit team komen bij gelegenheid van een videoreconstructie bijeen, waarna zij de videoreconstructie begeleiden en audiovisueel registreren. Het team, dat overigens geen officiële status heeft binnen de politieorganisatie, bestaat sinds het begin van de jaren 70 en wordt vanaf 2000 jaarlijks bij gemiddeld 15 reconstructies betrokken. In bijna $80 \%$ van de gereconstrueerde feiten betreft het een geweldsdelict met dodelijke afloop. Van de 90 onderzochte zaken, waarvan de uitspraak is gepubliceerd en die door het LVRT zijn begeleid en geregistreerd, blijkt in ruim $40 \%$ een beroep te zijn gedaan op een strafuitsluitingsgrond, in vrijwel alle gevallen noodweer(exces). Er kan uit de beschikbare gegevens worden afgeleid dat in de ene provincie de videoreconstructie vaker is ingezet dan in de andere. Voor dit verschil kan geen aantoonbare oorzaak worden aangetoond. Verder is vastgesteld dat de meeste videoreconstructies zijn uitgevoerd voor of tijdens de behandeling van de betreffende zaak door de rechtbank. Uit de beschikbare gegevens is afgeleid dat in de periode van 2000-2015 in ruim 7,7\% van de geregistreerde gevallen van moord en doodslag een videoreconstructie is uitgevoerd.

In hoofdstuk 4 wordt ingegaan op de positie van de videoreconstructie tijdens het voorbereidend onderzoek. De 'videoreconstructie' blijkt in tegenstelling tot enkele andere landen niet voor te komen in de Nederlandse wet- en regelgeving. Om die reden is aansluiting gezocht bij bestaande wet- en regelgeving die van toepassing is op onderdelen van de videoreconstructie, zoals het verhoor, de schouw, de vastlegging van opsporingsactiviteiten en het bewijs. Het verhoor vormt de basis van de videoreconstructie. Het richt zich bij een videoreconstructie vooral op het verkrijgen van informatie om het naspelen van de posities en handelingen mogelijk te maken en zo te komen tot audiovisualisering van de verklaring van de betrokkene. Een videoreconstructie wordt veelal op de oorspronkelijke plaats uitgevoerd. Om toegang tot deze plaats te krijgen kan gebruik worden gemaakt van de bepalingen rond de schouw. Verder is ingegaan op de videoreconstructie als deskundigenonderzoek, waarbij de vraag is gesteld of de begeleiderverhoorder en de verantwoordelijke voor de audiovisuele registratie als deskundigen moeten worden aangemerkt.

De volgende vier hoofdstukken richten zich op de relatie tussen theorie en praktijk. In deze hoofdstukken is beschreven welke juridische en rechtspsychologische normen en kwaliteitseisen voor de videoreconstructie gelden en is onderzocht hoe deze in de praktijk worden toegepast. Hierbij is het verloop gevolgd vanaf het voornemen tot het houden van een videoreconstructie, via de voorbereiding, uitvoering en registratie tot het gebruik ter terechtzitting. 
Het initiatief tot het houden van een videoreconstructie kan worden genomen door een van de professionele procespartijen. De rechter en het openbaar ministerie hebben een zelfstandige bevoegdheid om een videoreconstructie te laten uitvoeren. De verdediging heeft deze bevoegdheid niet en moet zich voor het houden van een videoreconstructie richten tot de rechter. Uit dit onderzoek is gebleken dat een verzoek van de verdediging regelmatig wordt afgewezen, waarbij door de rechter veelal het noodzaakcriterium wordt gehanteerd. Na een afwijzing van een verzoek kan de verdediging eventueel zelf een videoreconstructie uitvoeren. De kosten die hiermee gemoeid zijn en het feit dat zij geen toegang heeft tot een deskundige of deskundig team kunnen een barrière vormen. Verder heeft de verdediging in tegenstelling tot de rechter en de officier van justitie geen bevoegdheid tot het houden van een schouw en kan daardoor niet elke plaats betreden. De positie van de verdediging ten opzichte van die van de aanklager lijkt bij een videoreconstructie door de genoemde beperkingen op gespannen voet te staan met het beginsel van 'equality of arms'.

De aanleiding van een videoreconstructie is dat er onduidelijkheid is over de ware toedracht en of de professionele procespartijen hierover van mening verschillen. Uit de beschikbare draaiboeken van de videoreconstructies is gebleken dat in vrijwel alle zaken 'waarheidsvinding' als primair doel van de videoreconstructie wordt gesteld. Verder is gebleken dat in een aantal gevallen er specifieke doelen worden gesteld die vaak voortkomen uit de inhoud van de door betrokkenen afgelegde verklaringen, zoals tegengestelde of inconsistente verklaringen, verklaringen die in strijd lijken te zijn met het sporenbeeld, twijfels over de uitvoerbaarheid van handelingen, de aanwezigheid van gronden voor strafuitsluiting, audiovisuele waarnemingen van betrokkenen en het aandeel van afzonderlijke betrokkenen. Het komt ook voor dat de videoreconstructie wordt uitgevoerd ter ondersteuning van het oordeel van een deskundige. De videoreconstructie biedt vooral de mogelijkheid om verklaringen, al dan niet in relatie tot sporenbeelden en andere informatie uit het onderzoek te controleren, toetsen, verifiëren en falsificeren door het laten naspelen van posities en handelingen.

Nadat er een voornemen tot het houden van een videoreconstructie op initiatief van een van de professionele procespartijen is en besloten is daadwerkelijk tot de uitvoering over te gaan, wordt na een voorbespreking een aantal voorbereidingen getroffen. Bij de voorbespreking zijn vaak een officier van justitie, leden van het politieteam dat het onderzoek verricht en de teamleider van het LVRT aanwezig. In een enkel geval is ook de rechter-commissaris bij de voorbespreking aanwezig. In die gevallen neemt doorgaans ook de verdediging aan de voorbespreking deel. Bij de voorbespreking wordt een aantal zaken besproken en afgestemd, zoals de omvang van de reconstructie, de datum waarop de reconstructie plaats gaat vinden, welke verdachten en getuigen daarbij een rol zullen spelen, de locatie en de omstandigheden. Hierna worden de voorbereidingen getroffen, meestal door het onderzoeksteam van de politie in samenwerking met het LVRT.

De uitvoering van de videoreconstructie vindt meestal enkele maanden na de te reconstrueren gebeurtenis plaats. Aan de uitvoering wordt door een aantal actoren deelgenomen. Allereerst zijn dat de verdachten en getuigen, die bij een videoreconstructie 
de belangrijkste bronnen zijn. Door en op aanwijzing van elk van hen afzonderlijk wordt een reconstructie uitgevoerd. Daarbij wordt gebruik gemaakt van rekwisieten en plaatsvervangers. Deze plaatsvervangers dienen aan bepaalde voorwaarden te voldoen. Zij hebben vooraf bij voorkeur zo weinig mogelijk kennis van de gereconstrueerde gebeurtenis en komen qua postuur en lengte zoveel mogelijk overeen met degene die ze vervangen. De verdachten en getuigen worden bij hun reconstructie in vrijwel alle gevallen begeleid en verhoord door een lid van het LVRT. Hierbij is niet alleen juridische kennis vereist, maar ook kennis van diverse rechtspsychologische aspecten, zoals bronamnesia, het weaponfocuseffect, het mogelijke effect van herhaald bevragen en de mogelijk invloeden van het tijdsverloop tussen oorspronkelijke gebeurtenis en de reconstructie ervan. Verder is het gewenst dat de begeleider-verhoorder de beperkingen van een reconstructie kent. Op de plaats van handeling ziet hij ter ondersteuning van de technisch regisseur in de regieruimte toe op de wijze waarop de audiovisualisatie door de cameramensen wordt geregistreerd. Kennis van de impact van de wijze waarop de audiovisuele registratie wordt uitgevoerd is daarbij noodzakelijk.

Vrijwel elke videoreconstructie vindt plaats onder leiding en verantwoordelijkheid van een rechter-commissaris. In een enkel geval wordt hiervan afgeweken en neemt de officier van justitie deze positie in. In vrijwel alle onderzochte zaken blijkt de verdediging bij de uitvoering aanwezig te zijn.

Uit de enquête, die gehouden werd onder vertegenwoordigers van de professionele procespartijen, blijkt dat zij het van belang vinden dat de videoreconstructie wordt uitgevoerd op de oorspronkelijke plaats van het delict en onder zoveel mogelijk gelijke omstandigheden. Deze wens vindt ondersteuning vanuit rechtspsychologische inzichten over de waarde van deze voorwaarden voor het herinneringsvermogen van de verdachten en getuigen, die bij het delict betrokken zijn geweest. Retrieval cues, prikkels die het geheugen kunnen activeren, zoals de oorspronkelijke locatie en gelijke omstandigheden, spelen een belangrijke rol bij het realiseren van een betrouwbaar resultaat van de videoreconstructie. Het is belangrijk dat er sprake is van een unieke relatie tussen de prikkel en de specifieke herinnering. Is deze er niet dan kan dat leiden tot een dwaalspoor doordat er een andere herinnering aan de prikkel verbonden wordt. Het verloop van de reconstructie wordt met behulp van videocamera's audiovisueel geregistreerd. Tijdens de uitvoering van de videoreconstructie bevinden de vertegenwoordigers van de professionele procespartijen zich in een uitkijkruimte, waarin zij via een monitor het verloop van de reconstructie rechtstreeks kunnen volgen. Zij worden tijdens de uitvoering aan degene die de leiding heeft, meestal de rechter-commissaris, in de gelegenheid gesteld, hun wensen ten aanzien van de wijze van uitvoering kenbaar te maken. Na afloop van de videoreconstructie wordt in afstemming met de opdrachtgever een mediabestand gemaakt met de beelden van het verloop van de reconstructie en aan hem verstrekt, zodat deze nadien bij de behandeling van de zaak ter terechtzitting kunnen worden gebruikt.

In veel gevallen wordt de videoreconstructie gebruikt als onderdeel van het bewijs. De eigen waarneming van de rechter is bij uitstek het wettige bewijsmiddel voor de videoreconstructie. Ook lijkt de videoreconstructie een belangrijke rol te spelen bij de 
overtuiging van de rechter. Uit het onderzoek blijkt dat de videoreconstructie vooral een gevisualiseerde verklaring van een verdachte of getuige is die door middel van de wettige bewijsmiddelen van de eigen waarneming van de geregistreerde beelden en of een procesverbaal tot de rechter komt en zo kan bijdragen aan diens overtuiging.

Uit een analyse van de inhoud van de gepubliceerde uitspraken van zaken, waarin een videoreconstructie is uitgevoerd, blijkt dat de videoreconstructie in de meeste zaken vanuit het perspectief van de verdachte niet in zijn voordeel uitpakt. Dit is een opmerkelijke bevinding gelet op een eerdere constatering dat de verdediging, die belang heeft bij een ontlastend effect, vaker een videoreconstructie lijkt te wensen dan het openbaar ministerie.

Verder is aandacht besteed aan een bijzondere categorie, de videoreconstructies waarbij politiemensen of arrestantenverzorgers, die bij een geweldsdelict betrokken zijn geweest zich daarvoor strafrechtelijk moesten verantwoorden. Uit dat deelonderzoek blijkt dat bij die zaken het percentage videoreconstructies aanmerkelijk hoger ligt dan bij de geweldsdelicten, waarbij geen politiemensen zijn betrokken.

In het laatste hoofdstuk wordt een aantal conclusies getrokken en aanbevelingen gedaan. De onderzoeksbevindingen leiden tot de conclusie dat de videoreconstructie een belangrijke bijdrage kan leveren aan de waarheidsvinding. De videoreconstructie leidt in aanvulling op de mondelinge of schriftelijke verklaringen van verdachten en getuigen tot nieuwe audiovisuele informatie over de ware toedracht. Door handelingen en posities door en op aanwijzing van de bij het gereconstrueerde feit betrokken verdachten en getuigen na te spelen wordt gevisualiseerd wat zij bij het afleggen van hun verklaring daadwerkelijk bedoeld hebben. Met de nieuwe audiovisuele informatie kan de reconstructie van de toedracht, die meestal vooraf in de verbeelding wordt uitgevoerd, getoetst worden en daarmee levert de videoreconstructie een wezenlijke bijdrage, zoals ook is gebleken uit een aantal van de onderzochte 90 zaken, waarin een videoreconstructie was uitgevoerd. Verder blijkt dat er al vele jaren videoreconstructies worden uitgevoerd, waarbij het aantal op jaarbasis weliswaar enigszins fluctueert, maar over een langere periode nagenoeg gelijk blijft. Dit lijkt te bevestigen dat er bij de professionele procespartijen in een behoefte wordt voorzien en met een videoreconstructie door hen gestelde doelen worden gerealiseerd.

Er zijn op basis van de onderzoeksbevindingen acht aanbevelingen gedaan om de bijdrage van de videoreconstructie aan de waarheidsvinding te optimaliseren. Deze aanbevelingen zijn vooral gericht op de rechtmatigheid en betrouwbaarheid van de videoreconstructie. Er worden aanbevelingen gedaan over de status en de positie van de videoreconstructie in het strafproces, de leiding en verantwoordelijkheid tijdens een videoreconstructie, de positie van de verdediging en de beschikbaarheid en deskundigheid van verantwoordelijken voor de begeleiding en het verhoor van verdachten en getuigen en voor de audiovisuele registratie.

Tot slot is een eerste aanzet gegeven tot richtlijnen voor de videoreconstructie in het strafproces door het opstellen van protocol waarin een aantal uitgangspunten bij het voorbereiden, uitvoeren en audiovisueel registreren van videoreconstructies is opgenomen. 


\section{Bijlage $6 \quad$ Summary}

In this study, video reconstructions in Dutch criminal proceedings take a central role. From the start of a criminal investigation, different reconstruction methods are applied by different law enforcement officials in order to gain clarity about the circumstances surrounding the event under investigation. One of these reconstruction methods is video reconstruction. The event is re-enacted by and at the direction of persons involved in the event, who play the role of either suspect or witness, usually at the original location and under similar circumstances as they occurred during the event. These reconstructions take place upon request and in the presence of the professional parties to the proceedings and are audio-visually recorded.

The author of this dissertation is a member of the National Video Reconstruction Team (LVRT) and is a long-time expert in video reconstructions. In his PhD research, he asked himself how the way in which these video reconstructions are carried out relates to the law and regulations, and insights surrounding legal psychology. This need is reinforced by the lack of guidelines and publications of scientific research on this reconstruction method.

With video reconstruction, finding the truth is always the main goal. As such, the central question of this study is: 'In what way does video reconstruction contribute to finding the truth in criminal proceedings and how can that contribution be optimized?' The research was based on truth-finding in criminal proceedings, which consists of the reconstruction of facts for the purposes of making decisions in criminal matters. In the dissertation, the raison d'etre and the production of video reconstructions are analyzed in relation to the evidence and aspects of a fair process, such as the principle of equality of arms. The emphasis in the scientific analysis lies on determining the legality and reliability of video reconstructions.

In addition to literature and (media) messages, various sources have been used, such as the results of a survey, held among representatives of the professional parties, of which almost all have experience with video reconstruction. A case survey has also been conducted. During the period 2000-2015, several cases were examined in which a video reconstruction was carried out and of which the verdict was published on www.rechtspraak.nl. These number a total of 93 cases, 90 of which were led by the LVRT. Furthermore, information from the LVRT archive was collected and analyzed, a number of court files were examined and research was carried out on the video reconstructions provided by the LVRT during the aforementioned period, which were not published. The LVRT has led and recorded 243 video reconstructions during that period.

The dissertation is built up as follows. To gain an impression of the production and the essence of a video reconstruction, a fictitious case is presented after the first introductory chapter. As such, the reader is familiarized with the different steps: From the intention to perform a video reconstruction to the use and assessment of the outcome at the hearing. This case also provides insight into the parties involved and their role in the video reconstruction, and a number of areas of importance regarding the preparation and execution are identified. 
Chapter 3 contains quantitative and qualitative data on video reconstruction in the Netherlands. It also describes the LVRT in more detail. This is a team that operates nationally on behalf of the judge or the public prosecution service and consists of police officers working at the National Crime Squad (DNR) in East Brabant. The members of this team meet when a video reconstruction is required, after which they will lead the production of the video reconstruction through audio-visual recordings. The team, which has no official status within the police organization, has existed since the beginning of the 1970s and has been involved in an average of 15 reconstructions annually from 2000 onwards. In almost $80 \%$ of the reconstructed facts, it involves a violent crime with fatal consequences. Of the 90 cases examined - the verdicts of which were published and were led and recorded by the LVRTmore than $40 \%$ was appealed to waive the punishment, and almost all cases pleaded (excessive) self-defense. It can be deduced from the available data that video reconstructions were employed more often in one province than in the other. There is no demonstrable cause to explain this difference. It has also been established that most video reconstructions were carried out before or during the proceedings of the case in question. According to the available data, a video reconstruction was carried out in more than $7.7 \%$ of the recorded cases of homicide in the period 2000-2015.

Chapter 4 discusses the function of video reconstructions during the preliminary investigation. Unlike some other countries, video reconstructions do not appear in Dutch legislation and regulations. That is why complimentary laws and regulations to existing ones that apply to parts of the video reconstruction, such as the interrogation, the judge inspection, the recording of investigation activities and the evidence, are desirable. The interrogation forms the foundation of the video reconstruction. As such, it focuses mainly on obtaining information to enable the re-enactment of the positions and events that occurred at the time of the crime, and thus to create an audiovisual reconstruction of the concerned party's statement. A video reconstruction is often carried out at the original location. To gain access to this location, the provisions surrounding the judge's inspection can be used. Furthermore, video reconstruction has been considered as an expert study, raising the question whether the supervisor/interrogator and the person responsible for the audiovisual recordings should be regarded as experts.

The next four chapters focus on the relationship between theory and practice. These chapters describe the standards and quality requirements for video reconstructions surrounding legislation and legal psychology, and how they are applied in practice. Here, the course of action was followed from the intention to conduct a video reconstruction through preparation, execution and recording to its use at the hearing.

One of the professional parties to the proceedings can opt to initiate the production of a video reconstruction. The court and the public prosecution service have independent authority to have a video reconstruction carried out. The defense does not have this authority and must address the court to request a video reconstruction. This research has shown that a request from the defense is regularly rejected by the court because the criterion of self-defense is often not met according to the judge. After said request is rejected, the defense may opt to carry out a video reconstruction of its own accord. The costs involved 
and the fact that the defense does not have access to an expert or expert team may pose a barrier. Additionally, the defense, unlike the judge and the prosecutor, does not have the authority to carry out an inspection, and therefore does not have access to the crime scene. The position of the defense relative to that of the prosecutor seems to be at odds with the principle of equality of arms where video reconstructions are concerned due to the aforementioned restrictions.

A video reconstruction is conducted if there is uncertainty about the true circumstances surrounding the crime and whether the professional parties of the proceedings differ in their opinion on these circumstances. The available scripts for the video reconstruction show that, in almost all cases, finding the truth is set as the primary purpose of a video reconstruction. Furthermore, it has been found that in a number of cases, specific objectives are set which often arise from the content of the statements made by the parties concerned, such as contradictory or inconsistent statements, statements which appear to be contrary to the image created by any traces (or lack thereof), doubts as to the feasibility of actions, the presence of grounds for criminal exclusion, audiovisual observations of parties involved, and the number of individual parties. Video reconstructions are also sometimes produced to support an expert's assessment. Video reconstructions mainly offer the option to check, test, verify and falsify statements, whether or not in relation to images created by traces or other information from the investigation by re-enacting the positions and events surrounding the crime.

After one of the professional parties to the proceedings has decided to produce a video reconstruction, a number of preparations are made after preliminary discussion. The preliminary discussion often includes a public prosecutor, members of the police team conducting the investigation and the team leader of the LVRT. In one case, the examining judge was also present at the preliminary discussion. In these cases, the defense will usually also take part. In these preliminary discussions, a number of issues are addressed and coordinated, such as the size of the reconstruction, the date on which the reconstruction will take place, which suspects and witnesses will play a role in this, the location and the circumstances. The preparations are then made, usually by the police investigation team in cooperation with the LVRT.

The video reconstruction is usually performed several months after the event. The execution involves a number of actors. First of all the suspects and witnesses, who are the most important sources for a video reconstruction. A reconstruction is carried out by and at the direction of each of them separately. Props and substitutes are also used. These substitutes must meet certain conditions: They should preferably have as little prior knowledge of the reconstructed event as possible and correspond as much as possible to the person they replace in terms of posture and length. During the reconstruction, the suspects and witnesses are guided and interrogated by a member of the LVRT in almost all cases. This requires not only legal knowledge, but also knowledge of various legal psychological aspects, such as source amnesia, the weapon focus effect, the possible effect of repeated questioning and the possible influences of the time that has passed between the original event and its reconstruction. Furthermore, it is desirable that the supervisor-interrogator knows the 
limitations of a reconstruction. He will monitor the audiovisual recording of the camera operators and support the technical director at the location of the recording. Knowledge of the impact of the way in which the audiovisual recording is carried out is essential.

Almost every video reconstruction takes place under the guidance and responsibility of an examining judge. In a single case, the public prosecutor took up this position instead of the examining judge. In almost all the cases examined, the defense was present during production.

The survey, which was held among representatives of the professional parties to the proceedings, shows that they believe it is important that the video reconstruction is carried out at the original site of the crime and under the same circumstances to the greatest extent possible. This desire is supported by legal-psychological views on the value of these conditions for the memory of the suspects and witnesses who were involved in the crime. Retrieval cues, stimuli that can activate memory such as the original location and similar conditions, play an important role in achieving a reliable result for the video reconstruction. It is important that there is a unique relationship between the stimulus and the specific memory. If this link is not present, the recording might be misleading due to the stimulus triggering a different memory. The reconstruction is recorded audio-visually with video cameras. During the video reconstruction, the representatives of the professional parties to the proceedings monitor the reconstruction process directly from a viewing area. During the recording, they will be given the opportunity to express their wishes with regard to the manner in which the recording is carried out. They make their requests to the person in charge, which is usually the examining judge. At the end of the video reconstruction, a media file containing the recorded images is created in coordination with the client and provided to them so that it can be used for the hearing at the time of the proceedings.

In many cases, the video reconstruction is used as part of the evidence. The judge's own observations are the most legitimate means of validation for the video reconstruction. The video reconstruction also seems to play an important role in the judge's verdict. Research shows that a video reconstruction is primarily a visualized statement by a suspect or witness who, by means of submitting legal evidence containing their own experience of the recorded images and/or a police report to the judge, can thus contribute to the judge's verdict.

An analysis of the content of the published statements of cases in which a video reconstruction was carried out, shows that a video reconstruction, in most cases, is not beneficial to the suspect. This is a remarkable finding in view of an earlier finding that the defense, having an interest in a relieving effect, seems to want a video reconstruction more often than the public prosecution service.

Attention was also paid to a particular category: Video reconstructions in which police officers or detainee custody officers involved in a crime of violence have had to justify themselves in criminal law. This partial study shows that, in these cases, the percentage of video reconstructions is considerably higher than in violent crimes in which no police officers are involved. 
The last chapter draws a number of conclusions and makes a number of recommendations. The research findings lead to the conclusion that video reconstructions can make an important contribution to finding the truth. In addition to the oral or written statements of suspects and witnesses, a video reconstruction will lead to new audiovisual information on the true happenings of the crime. By re-enacting the positions and events by and under the instructions of the suspects and witnesses involved in the reconstructed event, their statements are produced visually in order to further clarify what they actually meant when giving their statements. With the new audiovisual information, the reconstruction of the crime, which is usually created in advance in the mind, can be tested. As such, video reconstruction offers a substantial contribution, as demonstrated by some of the 90 examined cases in which a video reconstruction was produced. It also shows that video reconstructions have been produced for many years and have largely stayed consistent in quantity over a longer period, with a slight annual fluctuation. This seems to confirm that they fulfill a need for the professional parties of the proceedings and that they can be used to achieve certain objectives.

Eight recommendations have been made based on the research findings in order to optimize the contribution of video reconstructions to truth-finding. These recommendations are mainly aimed at the legality and reliability of video reconstructions. Recommendations are made on the status and function of video reconstructions in criminal proceedings, the management and responsibility during a video reconstruction, the position of the defense, and the availability and expertise of those responsible for supervising and interrogating the suspects and witnesses and for the audiovisual recordings.

Finally, a start has been made on guidelines for video reconstructions in criminal proceedings by establishing a protocol that incorporates a number of principles for preparing, executing and the audiovisual recording of video reconstructions. 